\title{
The evolving intersection of planning and the commercial real estate market
}

Tommaso Gabrieli and Nicola Livingstone

$[6,985$ words $]$

\section{Introduction}

Urban planning is an active process, operating within fluid, dynamic markets and responding to varied regulatory systems, playing an integral performative role in the continual creation and recreation of the built environment. Harvey (1979) discusses how urbanism reflects spatial patterns and structures, which are mediated by man, with the city as an outcome, as a social product and consequence of many influences. The form and structure of planning and real estate institutions are key influences in this urban city creation, and the case of London today provides us with an opportunity to consider how the active processes of planning interact with commercial real estate investors and developers. It is the evolving intersection of these market actors, their functions and responses to policy and regulation shifts, the circulation of global capital and the increasing stream of international interest in London, which are considered here.

This chapter offers original insight into how professional networks and social relationships between planning and real estate actors within an established regulatory system intersect and inherently influence the cityscape of London on the global stage. Rather than considering these professionals as part of a wider institutional framework (see for example Myers, 2016; D’Arcy, 2009), the key objective of the chapter is to examine the evolving, particular experiences of planning and real estate 
professionals working in the London market today, and to consider how these interconnected roles have adapted in response to globalisation. Although planners and real estate actors interact and influence how cities are created, there has been little academic work which considers how their interconnected networks have evolved in the wider context of globalisation and market integration (with the exception of Theurillat et al (2015) who have examined real estate market 'players' in Switzerland). Specifically, we interrogate the relationships between the planning and real estate industries and their evolution within the London market since the onset of the global financial crisis (GFC) through semi-structured interviews with developers, investors and planning practitioners. We argue that the internationalisation of the commercial real estate sector, combined with deregulation and the resultant growth of private planning consultancies, has manifestly impacted how planning practices are expressed in the market, as planners strive to balance sustainable economic, social, and increasingly political interests, in a dynamic and demanding market environment.

The chapter begins by examining London's built environment and considers its present day position within the global market, from both real estate and planning perspectives. Following the market context, findings from the exploratory empirical research are discussed. These are considered thematically, and reflect on how planning practice has changed post-GFC; the challenges and tensions in relationships between planners and real estate professionals; financialisation and internationalisation; and concludes with thoughts on how planning and real estate professions will continue to evolve. The final section offers conclusions and recommendations for further research.

\section{Finance, globalisation and the built environment in London}

Amongst world cities, a small sub-set of cities known as international financial centres (IFC), play a major role in the global system of finance. Those cities act as centres for asset management and 
product innovation. Economies of scale and agglomeration, which are the benefits that firms obtain by respectively increasing in size and locating near each other, have resulted in an on-going concentration of high-order financial services - such as equity trading, bond trading, foreign exchange activity, derivatives trading and wealth management - in a few key global cities.

In a global economy dominated by the free and fast movement of international funds, IFCs compete with each other in order to attract capital, with London usually being considered one of the most global cities (Sassen, 2001). The attractiveness of London as a destination for both commercial and residential real estate capital has led to the city being been described as a 'safe deposit box' (Fernandez et al, 2016). There are key links between London and other global IFC's, as demonstrated throughout the GFC, where contagion effects were apparent in the global financial and real estate markets (Wojcik, 2013). Such market connections are also demonstrated through cycles, both at local market level and internationally (Weber, 2016; Jadevicius \& Huston, 2014; Grover \& Grover. 2014) as markets experience 'financialisation'. This relatively new term reflects the 'growing influence of capital markets, their intermediaries, and processes in contemporary economic and political life' (Pike \& Pollard, 2010: 30), where profit is made 'through financial channels rather than through trade and commodity production' (Krippner, 2005: 174). Financial flows into London have been growing steadily over past decades, as the city has experienced financialisation, creating new demand for office space and providing funds to transform the built environment, whose features are in turn a central factor in maintaining the capacity of the city to attract more capital. The decisions of investors, developers and planners are related to each other through real estate prices, financial returns and policy constraints.

However, the process of concentration of financial activities in a few cities may not continue as it has done in the recent past and the future of London and other IFCs is an open topic for debate, even more so after the UK voted to leave the EU. Strands of literature have argued to what extent developments 
in information and communications technology have transformed the nature of business and removed the need for agglomeration and city locations. In this respect, Lizieri (2009) suggests that one key factor to consider is the distinction between retail and wholesale activity and between high-volume, low-margin and low-volume, high-margin activities. Retail activity may be less likely to concentrate since it relies on customer knowledge, tastes, preferences and local marketing. By contrast, highvalue-added and low-volume businesses (e.g. corporate finance, fund management, mergers and acquisitions) rely on frequent client contact and information from a network of customers, rivals and parallel business, which leads to concentration. This complex interaction of agglomeration benefits, demand for central locations, creation and transformation of office space, which is mediated by market rents and prices, can explain the concentration of very diverse clusters of activities - ranging from the established financial and legal services to innovative start-ups and creative firms - into nearby areas of Central London. The future of the city presents many open questions ranging from the incentive of innovative firms to relocate away from expensive central areas, as they become more mature and either production or retail focused, to the wider impact of Brexit on the optimal location of high-order financial and related services.

The built environment of London has changed a lot in the past 30 years and has been characterized by significant development of new landmark office buildings as well as the redevelopment of former industrial areas, such as Canary Wharf and other sites in East London, into new mixed office/retail space. This activity is primarily a consequence of the demands for space from international financial service firms and other professional services that cluster around them. At the same time the availability of adequate and appropriate space for firms is a key competitive attribute of a city. Lizieri (2009) explains that this does not simply mean provision of large, new, technologically sophisticated office complexes. Outsourcing of activities and the need for niche service providers creates demand for a wide range of space, varying in size and quality. The real estate market is, hence, an important attribute of the agglomeration economies that promote clustering of financial activity. From this perspective, London has favoured agglomeration by the availability of a wide range of central space 
varying in size and quality through new construction and refurbishment of existing buildings, as well as the ability to satisfy the needs of clients in terms of technology, transport, amenities, and tailored support to international clients. Nevertheless there are on-going challenges for lower-value businesses and small-to-medium enterprises who may not be able to afford expensive central locations (see Ferm, Edwards and Jones, this volume).

In the complex picture that we are describing, real estate is not only a space in which business activities take place but also an investment asset and a store of value. For this reason, investment in and financing of real estate play a crucial role, since financial resources and expenditures impact the physical dimension. Investment and financing are intrinsically related and a mix of equity and debt instruments typically finances construction projects and investments in tenanted space. Equity investors in London-based real estate projects or real estate companies are typically foreign and domestic pension funds, or other institutional investors, who have traditionally found it optimal to hold real estate in mixed asset portfolios, because of an attractive risk/return profile or for diversification purposes. The widespread use of debt financing implies that lending to commercial real estate investors forms a significant part of banks' financial activity and a high proportion of banks' commercial real estate loans are secured on London offices. The size of international investments in London real estate assets has been growing over the last decades, with more than half of offices in the City now being owned by non-UK institutions. In global portfolio allocation strategies, investing in London real estate is often perceived as an expensive but safe option, which implies high asset prices and not necessarily high future returns, but with the benefit of relatively low volatility and low depreciation risk.

The famous Four Quadrant Model of DiPasquale and Wheaton (1992) is an essential analytical tool to understand how the complex interaction between development and investment inevitably creates market dynamics, volatility and cycles. See Miller (2015) for a video lecture on the model. 
Essentially, the model considers the specific and joint dynamics of property, investment and development markets, where shocks in one market will have an effect - albeit with lags - on other markets through changes in prices and rents. For example, a demand shock in the property market affects property valuations, which in turn will have an effect on investments for new constructions, which will ultimately feed-back as new supply to the property market, with the possibility of overshooting demand and therefore reversing the cycle. Most IFCs have experienced pronounced development cycles over the last 30 years and property cycles are a fundamental feature of real estate markets. Office rents are primarily determined by the demand for space that comes from firms. This demand is affected by the state of the economy, as well as shifts in the patterns of employment and changes in the way of working. Supply of new space by developers is also affected by economic and financial dynamics through the cost and availability of equity and debt. Shifts in supply and demand are expected to imply price adjustments: stronger demand causes price increases. Price increases would give an incentive to developers to build new space, but the resulting higher supply would in turn imply a downward re-adjustment of prices. Adjustments are slow because of the lags between a shift in demand, rental movements and the delivery of completed new offices. This contributes to the existence of natural development cycles of demand-driven appreciation and supply-driven depreciation. This natural cycle can be amplified by financial dynamics since periods of cheap financing would imply stronger demand for assets and higher real estate prices, but also more financing available for new supply that will follow. International capital flows make those linkages even more complex (see for example McAllister and Nanda (2016) for a recent analysis of the European office market) and prone to systemic risk (see Lizieri and Pain, 2014). There are also several behavioural elements in cycles: if developers, or their funders, are myopic then they may overreact to short-run upward rental and price trends, hence overbuilding and triggering over-supply that will, in turn, create downward pressure on rents and prices.

Asset market bubbles are defined as rapid price escalations that cannot be explained by underlying fundamental economic factors. The study of asset market bubbles is a widely investigated topic in 
finance and this has in turn inspired a sub-field that focuses on cycles and bubbles in real estate markets. Lizieri (2009), among many others, explains that commercial real estate has many characteristics which suggest that it should be prone to bubbles: high transaction costs and illiquidity which contribute to thin trading and lack of transparency, information asymmetry leading to the possibility of common shared errors, as well as heavy reliance on debt in capital structures. Moreover, financial and real estate markets are intrinsically connected. During all recent financial crises real estate markets have suffered particularly, whereas during recent financial booms they have been prone to bubbles. This happens because changes in the financial environment have an impact on firms' employment and demand for office space, therefore on vacancy rates, rents and ultimately on prices. Real estate market dynamics in turn feed back into the financial system, because the performance of real estate portfolios affects bank lending. Through this type of mechanism the 2007 sub-prime crisis led to the global financial crisis: a real estate shock triggered a banking crisis, which then spread to other areas of the financial and real economy.

Finance and globalisation in IFCs are linked with debates concerning the ability of the nation state to determine local economic and social activity. O’Brien (1992) and Martin (1994) discuss that financial market regulators no longer have full control over regulatory frameworks within the nation state and cities. As Lizieri (2009) points out, this is related to Castells' (1989: 254) concept of the space of flows "that now dominates and transcends the historically constructed space of places". We can therefore understand that in an economy where global financial flows increasingly affect the built environment, planners may not be able to control such external forces and therefore have less capacity to influence final outcomes. Indeed, the role of the state in the UK planning system has been increasingly 'hands-off' in recent decades, deregulation of the planning system being an example, as the state is intervening less in the market. 
A major challenge for the planning system in a globalized context comes from multi-level pressures. Newman and Thornley (2011) discuss in depth how the formulation of metropolitan strategies takes place within the context of urban politics and is shaped by the degree of power that is brought to bear by different interests. In a global world, the interplay between interests and planning priorities is not confined to the boundaries of city politics and they analyse the broad pressures from political, economic, environmental and cultural sources that shape a particular strategic planning agenda. This reveals a complex multi-level interaction between city-level pressures, and the regional and global level. The external forces may take the form of agencies that seek to influence or control the local political decisions and priorities, such as national governments, pressure groups or particular powerful business interests.

This has surely been the case for London over the last three decades with on-going changes to governance structures, and tensions between the various tiers of government. The flux is illustrated by the dismissal of the Greater London Council (GLC) in 1986, the consequent fragmentation of responsibilities between lower-tier boroughs with scarce coordination, and the recognized need for strategy and coordination that precipitated the creation of the Greater London Authority (GLA) in 1997. Questions remain around the tensions between resident groups and business lobbies - such as London First - and their respective impact on plans, as well as tensions created between the right of residents to oppose planning proposals and the central power to order plans with strategic interest, for example the High Speed 2 railway. In all the iterations of the London Plan, there has a focus on maintaining international competitiveness being one of (or possibly the) primary objective. Sustaining London's economic success is often interpreted as ensuring growing global financial flows into London, thereby re-enforcing the dynamics that have been illustrated in this section.

\section{London: present-day professional reflections}


This section of the chapter unpacks the empirical, primary research carried out which reflects the 'real-life experiences' (Chang, 2011) of planning and real estate market professionals working in London today. As there is negligible academic precedent for this type of work, semi-structured interviews were used to identify emerging themes in relation to industry networks. Five in-depth semi-structured and exploratory interviews were carried out, providing a qualitative foundation for the development of further work in this area. Each interview represents the perspective of a different market actor (public sector planner, private sector planner, real estate developer, investor, agent) and in essence reflects five detailed and individual case studies of market experiences. From these case study interviews four key themes emerged, which offer insight into the networks of professionals operating in London, and their experiences of the regulatory system, the commercial market, the internationalisation of the city and their evolving, networked roles in the market. When reflecting on the changes in the London market since the GFC and in the longer term, interviewees emphasised the issues faced by built environment professionals in negotiating an increasingly political and deregulated planning system, the shifting roles of public and private actors at play in the market, and London's position in the global market as an IFC. The four emerging themes are discussed in the following sub-sections.

Perceptions of the evolving role of planners: what's changed?

All of the interviewees discussed how the public sector planning system has become increasingly political - a tool adopted by politicians to meet their own specific needs. Planners are seen as "high up the pecking order for cuts," as "politicians view planning as a negative force, they talk of delays in the system, constraints, lack of flexibility..." and therefore, this acts as a "break on the economy and the growth of London". However, such comments are more directly linked to the overall philosophy of the state itself and its much reduced role in the market. 
The withdrawal of the state has left the public sector planning system fulfilling a more reactive, rather than proactive role, in the networks of actors operating in London. Although the negative perception of the planning sector by politicians in central government is not necessarily a new phenomenon, today it is one that is acutely affecting the operation of the planning system, reflecting "poor political leadership and [a] lack of understanding of how important it is to empower people if you want a professional service". Typically "delays in the planning system are political, not professional." Indeed, a number of interviewees were keen to strongly emphasise that the role of the public planner "has fundamentally not changed, [but] the role of the state has changed quite dramatically". Indeed, public planners are, across the board seen to be fulfilling their function to the best of their abilities, and that although it would be ideal if planning could be transacted more quickly, most issues experienced by interviewees relate to "resourcing in local authorities and not the professionalism of the planners. Local authorities are respected, but squeezed."

Concomitant to this squeeze in local authority public sector planning, the private sector planning profession has seen significant growth (see Raco, this volume). Networks of service providers now typically operate as 'consultants', with planners, real estate development, and investment agents, all working within dedicated global built environment services companies. Some interviewees implied that in part, this move towards the private sector for planners reflects how the public sector professionals are failing to keep up with market shifts and are "almost being caught behind the curve in terms of the wider economy and the local plans, there is a need to innovate". Currently, the "private sector does appear to be better at delivering projects, skills in the private sector now seem to be stronger than the public sector" and there is currently "less specialist knowledge in the public sector". When considering the efficacy of the planning and development process (public and private), the role of the market and its regulatory policies are clearly a considerable influence, one which is impacted by a variety of different networks of individuals and companies in the built environment (construction 
companies, architects, surveyors). Through such networks, public and private sector actors come together. One interviewee explains that the development process is largely market driven and the role of public planners is often to select between different proposals from the private sector. Between those different proposals the planner may choose the one that satisfies most of, or rather the preferred, policy objectives. Indeed, "a lot of developments that have been supported have been because the local planning staff have been supportive and interpreted those developments within the local plan context and their localities objectives". However, due to such interpretation it is very rare that all the policy objectives will be satisfied; the planners (and often other actors involved) are likely to have to accept a compromise and trade-offs between different policy objectives. The planning consultant for the private developer potentially has a greater impact on the outcome because they have the responsibility to present the trade-offs and argue for compromises:

There are so many policies and they are so far reaching in terms of car parking spaces, building materials, height of the building, affordable housing targets, uses that are protected, uses that are encouraged...it would be almost impossible to design a scheme that ticks every single policy box...there is no situation where you are not going to have to compromise on some of those big policy issues ... And it is the role of the applicant to set out the compromises.

In these circumstances, the role of public and private planners today is clearly very different. One interviewee commented that agents acting for developers are "toughening up their act, in parallel with public sector services being disenfranchised in some ways and losing resources," reinforcing the perspective that private sector planners active in the market today potentially play more powerful roles than public sector planners. In particular, when it comes to compromises and trade-offs the private sector planner is seen as having greater leverage. However, both the public and private sector actors are playing an essential role in the development process, their motivations and positions may be contrasting, but they are each working towards a successful, potentially compromised outcome. One 
interviewee suggests that these contrasting motivations may prove to be problematic if antagonisms between actors are exacerbated in the longer term. They suggest that although "drivers of public and private sector [actors] are very different, it is a bad thing if the balance goes too far in the direction of the private sector, because the public sector is what gives changes in the [planning] environment a credibility, and a kind of legitimacy." Public sector planning continues to embody the "democratic foundation' of the planning system in the United Kingdom.

\section{Active challenges \& embedded tensions in relationship networks}

It has already been established that planning is becoming increasingly political, and is today a "relatively unsettled profession which has been exploited by the politicians". A profession which, in the public sector, is perceived to be falling behind the curve and not adjusting quickly enough to market shifts. It can also be argued that the political orientation of the planning committee is often the factor that may strike the balance in one direction or another.

Politics plays a major role in the decisions over policy objectives. Ultimately reasonable sized applications are decided by local planning committees, made up of locally elected representatives, who are members of political parties; so it is about their policy objectives more than anything else. The planner knows to an extent what is viable, but the reality is that he/she says 'If I can only do this or that, I will only do what is politically acceptable, or desirable'.

Therefore, when it comes to reaching an agreement on an application through the consultation process, there are expected trade-offs between communities, planners and policymakers, trade-offs which are inherently influenced not only by built environment professionals, but also the local politics. When planning applications are submitted there is typically "huge cynicism towards developers... you are starting at square one with [most] of the local community." Often, when 
interacting with the local community to consult on a development there is clearly "a lack of knowledge and education of the people on the planning committees, the members of the local authority who will often push back against the [planning] officer's recommendations because they have simply not understood the product." It was suggested that real estate developers who adopt a more long term approach to creating a successful development, and who intend to retain the development moving into the future rather than selling on, approach the consultation process in a more successful and proactive way with the local communities.

However, whether the developer has a short or long term interest, an additional challenge that was identified was the consultation and application process itself (for perspective on this see Beebeejaun, this volume). Across a number of interviews, there was generally thought to be a "lack of good consultation at the start of the planning process", a need for local authorities to be more proactive and for an earlier start to consultation. Interacting with the local community and planning committee earlier in the process would ensure that the community feels their opinions are valued as "people need to play a role and have ownership of the plan making process" in a more effective way. This could, potentially, help to diffuse the issues faced by developers in overcoming conflict in local areas, but also in potentially speeding up the planning process itself and improving those all-important networked relationships.

The so-called 'financialisation' \& 'internationalisation' of the city

Findings in this section reflect a shift from discussing the more localised networks of actors in manoeuvring the planning system, and moves to more of a global narrative, which considers the role London currently plays in the world market as "huge amounts are capital are attracted to London, it is 
seen as a safe haven, and hugely experienced people use the best consultants and joint ventures" to facilitate and execute their real estate activities in the city.

The London "real estate sector is a global stage, and a significant amount of capital is coming in from different jurisdictions across the world", and there is "nothing at all wrong with inward investment, as long as it is active. But if it isn't realising its potential, if it is being used as a security deposit box, then that is a bad investment". Interviewees emphasised the need for real estate investors and developers to take a longer term approach and interest. The capital flowing into the city should deliver additional benefits to the local community and not just maximise profits. Many real estate investors already take that approach, and it is recognised that part of the seemingly perpetual negative rhetoric surrounding international investors in the last decade isn't an accurate representation of the reality. In this respect, "perhaps in the past there hasn't been enough emphasis on the overall, non-monetary benefits that are delivered through development, and perhaps too much emphasis on extracting the maximum value of the land". Private sector actors have been seen to provide clear community "value add' in a number of developments across London, such as Capco's ongoing interest in Covent Garden and the public-private partnership currently active in redeveloping the Woodberry Down estate in Hackney. One interviewee discussed Argent, who redeveloped and transformed Kings Cross from a neglected to regenerated area of the city, as an obvious example of successful private development, influenced by the international market. Argent are owned by Hermes Investment Management, which is a UK domiciled company operating on a global scale. Although viewed as success in urban design and putting Kings Cross 'on the map' in terms of investment, the development attracted controversy due to the displacement of residents and businesses, as well as issues surrounding "publicly owned private spaces' and affordable housing provision. These issues are not unusual in the London market and scepticism persists in relation to international flows of capital coming into the city, specifically from the East, with questions raised over "whether the new owners will have as much interest in the future interest and vibrancy of the surrounding areas". A clear example of how investments from the East currently affect surrounding areas is the Olympic Village at Stratford. Prior to the Olympic 
Games in London in 2012, the Athletes Village was sold to Qatari Diar (Qatar's Real Estate Investment Company) and Delancey Estates (UK investors). Even with wider concerns over the internationalisation of London, it is not a case of international developers profiting exclusively to the detriment of local communities, rather the antagonisms persisting in the London market are nuanced and complex. The planner's role in mediating between investor and developer requirements and community and social needs in culturally specific contexts reflects the need for balanced and careful application of specialist knowledge between all involved parties.

Developers and investors want a well-informed "route to knowledge, [with] speed and certainty," and they depend upon the specialised knowledge of the planners involved in achieving the overall aim of spreading capital across London's built environment. There is clearly an element of trust in a planning consultant's capacity to provide appropriate professional advice and information on, for example, market specific planning practices, policies and regulations. However, there is also an element of market competition, as if services provided are not deemed efficient, or effective enough, then the real estate developers and investors can find another planning consultancy which replicates services provided. Therefore, the financialisation and internationalisation of the real estate market in London has both stimulated growth in private sector planning due to increased demand for services, as well as fuelling competition between private planning consultancies.

As London's perception as a "safe deposit box" has emerged, the city has become consistently attractive to potential developers and investors, with the private sector planning knowledge initially, combined with the public sector interaction latterly, influencing progress and potential success. Although the public sector planning system has been squeezed, the private sector planning and real estate consultancies have continued to grow significantly, becoming key to executing developments and investments. In this respect, international actors especially rely on the local professional planning and real estate services to accurately inform and support their decision-making process. As a 
corollary, if the so-called route to knowledge is clear, then such actors are "likely to be much more flexible, likely to adapt their schemes and negotiate in all sorts of ways", in order to spread their capital into London. So, on the flipside, rather than local planning officers considering accepted policy related compromises, the real estate developers and investors are also often willing to consider making concessions. Such is the appeal of London as an IFC with an established global real estate market. These international developers and investors are seen as more able to "manoeuvre the system over time", as due to the capital under their command, they have the luxury of being able and willing to be patient, waiting for the best opportunities that emerge in line with their strategic needs in the capital. From such comments, it is clear that there are temporal, strategic and power relations at play in the London, as international investors and developers seek to achieve particular objectives, in a highly competitive market. The roles of both public and private sector planners are inherent to achieving these objectives and providing reliable, up-to-date professional knowledge and counsel.

\section{Market processes and public land use}

The final key theme of the interviews was related to the future and how planning may continue to evolve, across the structures of the built environment profession and regulatory environment. Much was discussed about the lack of effective use of public land, and the potential benefits that could emerge from blending public and private responses to market driven built environment processes in London. The market driven process of development is described as an efficient process in terms of the use of resources. "One can look at the past and see mistakes, for example a lot of regeneration schemes from the 90's have built two-storey buildings in areas that are now central and prime, which would be considered today to be a very inefficient use of land ... but one can argue that at the time, given those market conditions, that was an efficient use of land." The advocated reason is that, in London, the land market is so competitive that inevitably a developer is forced to optimize the site to get the most benefit out of it for all involved parties, and sites which were developed historically are not providing at their optimal potential today (from residential, commercial or density perspectives). 
Having said that, one of the major inefficiencies seems to be the use of public land. One interviewee argued that Councils can often acquire land for development at nil cost or borrow money relatively cheaply, whereas it is very expensive for the developer. However, local authorities rarely use this as an opportunity for public-led development and in general could use and manage land more efficiently given the policy objectives. An interviewee provides a hypothetical example below, reflecting on current practice:

A council could take land and develop it itself and achieve a 100\% affordable housing rate, rather than selling the land to the private developer, or it could develop it with better quality materials....[But] the way that public land has been managed is disposal to the open market, because of a perceived statutory obligation to achieve best consideration ... and best consideration has been interpreted as highest capital receipts ... and the way to obtain highest capital receipts is to dispose it to the highest bidder who pays the highest land value ... and the reason that they can pay the highest value is because they have been more bullish on the assumptions that they make, which often implies that they will build less affordable housing and build more cheaply.

It is also argued that even this is largely a political decision and that if best consideration was interpreted as that which achieves the best social benefits, as well as profits, the council could go into a joint venture, partnership or covenant the land. This has started to happen with some recent schemes, for example the construction of Bernard Wetherill House through the Croydon Urban Regeneration Vehicle, which partnered Croydon Council and John Laing (2008-2016). As another interviewee noted, certain local authorities in addition to Croydon, such as Ealing and Barking, are beginning to develop more strategic visions in relation to what they do with their land and emerging potential development opportunities. There is a need for local authorities to become more proactive in the planning process once more and to approach opportunities by "thinking outside the box". In looking to the future and striving towards a more fluidly functioning market of both global and local 
networks of actors, "the answers lie... with building bridges to bring groups together to achieve the best we can deliver and be positive".

\section{Concluding thoughts}

This chapter has reflected on how professional networks and social relationships between planning and real estate actors within an established regulatory system intersect and inherently influence the cityscape of London on the global stage. It emphasises the role of global financial flows; how those are the main drivers of real estate activity; how this implies the need for a planning system that facilitates the capacity of a global city to continue to attract new global flows; and how this implies new challenges for planners. Despite our inevitable focus on London, this being one of the most global IFCs, our reflections could inspire or guide further research on other IFCs and competitiveness in regional cities.

The clear message that emerges from our research is that the built environment in London functions as a myriad collection of networked institutional roles. These reflect the regulatory 'rules of the game' and the interpretation of policies (such as local plans), and demonstrate how the state, although influential and key to the creation of the city as an important IFC, is inclined to let the market be interpreted by specialised professionals and adopt more neoliberal approaches to planning and the economy. However, specific politicians and parties active on the ground, and in localities, are now adopting planning as a mechanism they can use to affect change in the real estate market - depending on whether it is interpreted as positive or negative, and funded by domestic or international capital. It is clear that politics now plays a significant role in the market and affects how both local and national politicians and perceived. 
Both public and private sector planners are key to the successful completion and integration of new developments into local communities and the wider city. Although the private sector is viewed as being more proactive, compared to the more squeezed and now reactive public sector, each play important roles in the development process. There is some beauty in this difference, as it reflects how the planning system as a whole has adopted and responded to both the needs of investors and developers, and the state. There appears to be, at present in the London market, a precarious balance between the functions of different actors and companies, which are operating within the rules of the game, but representing varied perspectives and points of view. The importance of communicating these points of view to the local communities through an effective consultation process cannot be understated. There appears to be a need to integrate local community perspectives earlier in the planning process, to ensure a smoother, more successful negotiated outcome for all parties involved. The activities of the local community and local planning committees can clearly have an impact on how a development proceeds and is perceived. The impact of the 'local' cannot be understated, as consultation can affect outcomes for small-scale, capital-light local companies, to large-scale international, capital-heavy investors. Although London as an international market is seen as accessible, transparent and a 'safe haven' for many, the notion of market convergence can be somewhat contradicted due to the realities of planning and developing in local authorities. The market dynamics of real estate and planning actors, as well as other built environment professionals active in London today, are flexible and fluid (although change may come more quickly in the private rather than public sector). Networked relationships play a significant role, as each try and achieve the best outcome under 'best consideration' and 'highest and best use', for burgeoning developments in the city. The companies themselves are competitive and strategic in their approach to clients and the demands on their services, especially within the private sector. However, moving forward there may be a need for both public and private planners to 'think outside the box' and continue to evolve their roles, in order to successfully respond to the new challenges arising from their networked and increasingly intersected relationships. As cities continue to develop and become increasingly 'financialised', planners and real estate professionals must continue to adapt and 
effectively respond to both investors and developers in a highly competitive market, which inherently incorporates perspectives from the local to global.

\section{References}

Castells, M. (1989) 'The Informational City: Information Technology, Economic Restructuring, and the Urban-Regional Process' Oxford: Blackwell.

Chang, H. (2011) 'Institutions and economic development: theory, policy and history'. Journal of Institutional Economics, Vol.7, No.4, pp.473-498.

D'Arcy, E. (2009) 'The evolution of institutional arrangements to support the internationalisation of real estate involvements: Some evidence from Europe', Journal of European Real Estate Research, Vol.2: pp. 280-293.

DiPasquale, D. \& Wheaton, W. (1992) 'The Markets for Real Estate Assets and Space: A Conceptual Framework'. Journal of the American Real Estate and Urban Economics Association, Vol. 20 No2, pp. 181-197.

Fernandez, R., Hofman, A. \& Aalbers, M. (2016) 'London and New York as a safe deposit box for the transnational wealth elite'. Environment \& Planning A, Vol.48, No. 12, pp. 2443-2461.

Harvey, D. (1979) ‘Social Justice and the City'. Edward Arnold, London.

Grover, R. \& Grover, C. (2014) 'Property bubbles - a transitory phenomenon'. Journal of Property Investment \& Finance, Vol. 32, No.2, pp. 208-222. 
Jadevicius, A. \& Huston, S. (2014) 'A “family of cycles” - major and auxiliary business cycles'. Journal of Property Investment \& Finance, Vol. 32, No.3, pp.306-323.

Krippner, G. (2005) 'The Financialization of the American Economy'. Socio-Economic Review, No. 3, pp. 173-208.

Lizieri, C (2009) 'Towers of Capital: Office Markets \& International Financial Services', WileyBlackwell.

Martin, R. (1994) 'Stateless Money, Global Financial Integration and National Economic Autonomy: the End of Geography', in Corbridge, S., Martin, R. and Thrift, N. (eds), Money, Power and Space, Oxford: Blackwell.

Miller (2015) 'Explaining the Four Quadrant Model', educational video on youtube standard licence, https://www.youtube.com/watch?time_continue $=586 \& \mathrm{v}=\mathrm{kVwHvliV} 1 \mathrm{pA}$

Myers, D. (2016) 'New Economic Thinking and Real estate'. Chichester: Wiley.

McAllister, P. \& Nanda, A. (2016) 'Do Foreign Buyers Compress Office Real Estate Cap Rates?' Journal of Real Estate Research, Vol. 38, No. 4, pp. 569-594.

Newman, P. and Thornley, A. (2001) 'Planning World Cities: Globalization and Urban Politics' Palgrave Macmillan.

O'Brien, R. (1992) 'Global Financial Integration: The End of Geography’ London: RIIA. 
Lizieri, C. \& Pain, K. (2014) International Office Investment in Global Cities: The Production of Financial Space and Systemic Risk, Regional Studies, Vol. 48, No 3, pp. 439-455.

Pike, A. \& Pollard, J. (2010) ‘Economic geographies of financialization’. Economic Geography, Vol.86, No.1, pp.26-51.

Sajor, E. (2005) 'Professionalisation or hybridisation? Real estate brokers in Metro Cebu, the Philippines, during the boom of the 1990s'. Urban Studies, Vol. 42, pp. 1321-1343.

Sassen (2001) 'The Global City: New York, London, Tokyo', Princeton University Press.

Theurillat, T., Rerat, P. \& Crevoisier, O. (2015) 'The real estate market: Players, institutions and territories'. Urban Studies, Vol. 52, No. 8, pp. 1414-1433.

Weber, R. (2016) 'Performing property cycles'. Journal of Cultural Economy, Vol.9: 6, pp.587-603.

Wojcik, D. (2013) 'The Dark side of NY-LON: Financial Centres and the Global Financial Crisis'. Urban Studies, Vol. 50, No. 13, pp. 2736-2752. 